\title{
Time-variations of equivalent water heights from Grace Mission and in-situ river stages in the Amazon basin
}

\author{
Flavio Guilherme Vaz de ALMEIDA ${ }^{1,2}$, Stephane CALMANT ${ }^{2}$, Frédérique SEYLER ${ }^{3}$, Guillaume \\ RAMILLIEN $^{4}$, Denizar BLITZKOW ${ }^{1}$, Ana Cristina Cancoro MATOS ${ }^{1}$, Joecila Santos SILVA ${ }^{5}$
}

\begin{abstract}
Gravity Recovery and Climate Experiment (GRACE) mission is dedicated to measuring temporal variations of the Earth's gravity field. In this study, the Stokes coefficients made available by Groupe de Recherche en Géodésie Spatiale (GRGS) at a 10day interval were converted into equivalent water height (EWH) for a $\sim 4$-year period in the Amazon basin (from July-2002 to May-2006). The seasonal amplitudes of EWH signal are the largest on the surface of Earth and reach $-1250 \mathrm{~mm}$ at that basin's center. Error budget represents $\sim 130 \mathrm{~mm}$ of EWH, including formal errors on Stokes coefficient, leakage errors (12 $21 \mathrm{~mm})$ and spectrum truncation $(10-15 \mathrm{~mm})$. Comparison between in situ river level time series measured at 233 groundbased hydrometric stations (HS) in the Amazon basin and vertically-integrated EWH derived from GRACE is carried out in this paper. Although EWH and HS measure different water bodies, in most of the cases a high correlation (up to $\sim 80 \%$ ) is detected between the HS series and EWH series at the same site. This correlation allows adjusting linear relationships between in situ and GRACE-based series for the major tributaries of the Amazon river. The regression coefficients decrease from up to down stream along the rivers reaching the theoretical value 1 at the Amazon's mouth in the Atlantic Ocean. The variation of the regression coefficients versus the distance from estuary is analysed for the largest rivers in the basin. In a second step, a classification of the proportionality between in situ and GRACE time-series is proposed.
\end{abstract}

KEYWORDS: Spatial geodesy, hydrology, GRACE satellite, Amazon Basin.

\section{Variações temporais do equivalente à altura d'água obtidas da Missão Grace e da altura d'água in-situ nos rios da bacia Amazônica}

\begin{abstract}
RESUMO
A missão espacial Gravity Recovery and Climate Experiment (GRACE) é dedicada às medidas das variaçôes temporais no campo gravitacional da Terra. Neste estudo, os coeficientes de Stokes disponibilizados pelo Groupe de Recherche en Géodésie Spatiale (GRGS) com intervalos de 10 dias foram convertidos no equivalente à altura d'água (EWH) para um período de 4 anos na bacia Amazônica (de julho de 2002 a maio de 2006). As amplitudes sazonais do EWH no centro da bacia são as maiores encontradas no mundo $(-1250 \mathrm{~mm})$. Os erros na estimativa do EWH são de $\sim 130 \mathrm{~mm}$, incluindo os erros nos coeficientes de Stokes, erros de vazamento de informaçóes das bacias vizinhas $(12 \sim 21 \mathrm{~mm})$ e truncamento do espectro $(10 \sim 15 \mathrm{~mm})$. Neste trabalho, são feitas comparações entre as informaçôes de altura d'água in-situ medidas em 233 estaçôes hidrológicas (HS) na bacia Amazônica com EWH obtido pelo GRACE. Embora o EWH e as HS meçam diferentes corpos d'água, na maioria dos casos, uma alta correlação (até 80\%) é encontrada entre ambas as séries ao mesmo local. Esta alta correlação permite ajustar uma relação linear entre as séries para os maiores tributários do rio Amazonas. O coeficiente de regressão decresce da montante para a vazante, tendendo para o valor teórico 1 na foz do rio Amazonas. A variação deste coeficiente versus a distância ao estuário é analisada para os maiores rios da bacia. Em uma segunda etapa, uma classificação da defasagem entre as séries dos dados in-situ e GRACE são apresentadas.
\end{abstract}

PalaVras Chave: Geodesia Espacial, Hidrologia, Satélite GRACE, Bacia Amazônica.

\footnotetext{
${ }^{1}$ Escola Politécnica da Universidade de São Paulo, Departamento de Engenharia de Transportes - PTR-EPUSP, São Paulo, Brazil.

${ }^{2}$ Laboratoire d'Etudes en Géophysique et Océanographie Spatiales, UMR 5566, CNRS/CNES/RD, Observatoire Midi-Pyrénées, Toulouse, France.

${ }^{3}$ US ESPACE, IRD, Montpellier, France.

${ }^{4}$ Dynamique Terrestre et Planétaire (DTP) - UMR 5562 - Observatoire Midi-Pyrénées, Toulouse, France.

${ }^{5}$ Universidade Federal do Rio de Janeiro UFRJ - COPPE - Rio de Janeiro, Brazil.
} 


\section{INTRODUCTION}

The Amazon Basin is considered the largest hydrographic river basin in the world with -6.1 million $\mathrm{km}^{2}$, extending from the Andes to the Atlantic Ocean. The large range of water level annual variations and the large inundated area (rivers and flood plains) in the Amazon basin, give rise to an important seasonal water mass change; hence gravitational variations. These hydrological variations have been detected by the Gravity Recovery And Climate Experiment (GRACE) geodetic mission for several years. GRACE mission is a Deutsches Zentrum für Luft und Raumfahrt (DLR) and National Aeronautics and Space Administration (NASA) joint venture launched in March 2002 initially-planned for a time span of at least five years (Tapley et al., 2004a). The objective of GRACE is to measure accurately the variations of the gravitational field of the Earth on a monthly basis. On land, temporal variations are mainly due to changes inland water storage related to climate variability and anthropogenic factors. Several studies have shown that GRACE is able to detect land water storage change in large river basins especially seasonal water cycles (Tapley et al., 2004b; Wahr et al., 2004; Schmidt et al., 2006; Ramillien et al., 2008; Schmidt et al., 2008).

The purpose of this paper is to study the linear relationship between the water mass distribution and the superficial water circulation within the basin. This relationship is appraised by comparing the time-variations of water stage in rivers in situ gauges and the gravitational signature measured by GRACE. The proposed method is based on two steps: (1) the computation of the linear correlations between the two types of data by least square adjustment of the best strait line fitting regression if the correlation is greater than 70 per cent, (2) analysis of the proportionality of the series pairs.

The study area is comprised between latitudes $4^{\circ} \mathrm{N}$ to $10^{\circ} \mathrm{S}$ and longitudes $49^{\circ} \mathrm{W}$ to $71^{\circ} \mathrm{W}$, including most of the Amazon basin and centered on the maximum variation of the GRACE signal (Figure 1).

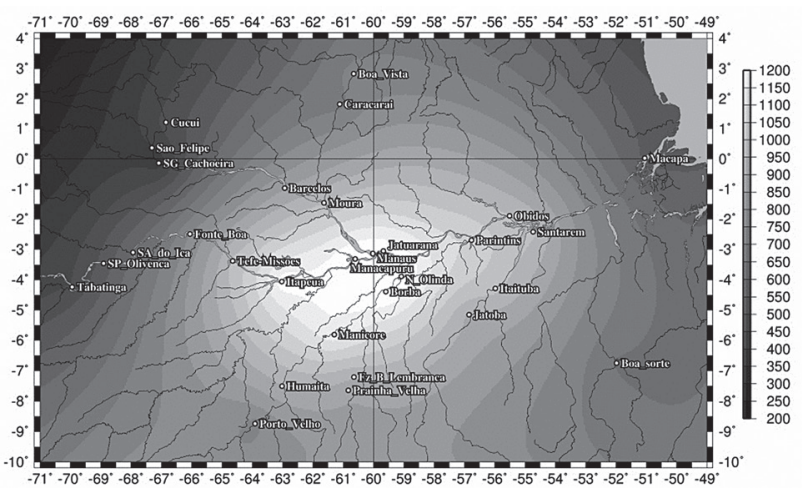

Figure 1 - Delimited study area, hydrological stations and water-level amplitude deduced from GRACE

\section{MATERIAL AND METHODS}

\section{Data sets}

The data set used consists of 233 pairs of time series. Each pair is formed by (1) in situ water level measurements provided by Agência Nacional de Águas (ANA); (2) 10-day GRACE data geoid variations computed by Biancale et al. (2006) and converted into equivalent water-height (EWH) (Ramillien et al., 2005). The data sets are detailed in the following.

\section{In situ water level measurements from ANA ground- based stations}

The methodology of acquisition is based on daily in situ water level data, by visually reading the water level value on the limnimeter scale. These data are collected by the ANA and distributed through their website (ANA, 2006). The HS data quality depends of the visual reading processes and some systematic errors were detected in some stations. This kind of stations was rejected and, if possible, a bias correction factor was applied to eliminate the periodic gap. In order to make the HS data sampling consistent with the EWH series, running averages were performed over 30-day periods as three 10-day periods with weights $0.5 / 1.0 / 0.5$. The reference date for each period was taken as the central day.

Uncertainty on the in situ levels is fixed at 2 centimeters, twice ruler scale. For the purpose of this study, curvilinear distances along flow path have been computed between the gauge and the river mouth. Further on, distances are always understood this way. The distance uncertainty was estimated in $-1.5 \%$.

\section{GRACE Data}

The 128 Level-2 GRACE solutions computed by the GRGS in Toulouse, France (Biancale et al., 2006; Lemoine et al., 2007; Bruinsma et al., 2010) were used. The provided Stokes coefficients (i.e., the dimensionless harmonic coefficients of the geo-potential) were adjusted from along-track orbit observations of gravitational potential perturbation, and corrected for atmosphere mass change using European Centre of Medium-Range for Weather Forecast (ECMWF) re-analysis and oceanic mass using the barotropic 2D gravity wave model (MOG-2D), and tides effects from Finite Element Solution (FES) tide model called FES2004 (Lyard et al., 2006). The remaining gravity signals should represent the surface water mass variations that were not explicitly modeled, thus mainly the continental hydrology. Monthly Stokes coefficients are provided up to degree and order 50, which is equivalent to a surface spatial resolution of $-400 \mathrm{~km}$. Each GRGS GRACE solution is shifted by 10 days from the previous one, and computed as a weighted average of about one month of GRACE data using the 10-day factors $0.5 / 1 / 0.5$. In this processing, the spectrum of the monthly 
solution is forced for harmonic degrees less than 30 to be less than a reference, which is empirically derived from the variance spectrum of the static gravity field (i.e., Kaula's rule). This stabilization scheme of the short-wavelength coefficients attenuates the unrealistic North-South striping by acting as a low-pass filter. GRGS also provides the uncertainties associated to the GRACE-based Stokes coefficients for each monthly period.

The monthly time-variable anomaly $\delta G(t)$ can be computed as a difference between the monthly solution $G(t)$ and the mean temporal stationary solution $G_{O}$ (Ramillien et al., 2005):

$$
\delta G(t)=G(t)-G_{O}
$$

Thus, $\delta G(t)$ can be developed as a series of spherical harmonic coefficients:

$G(t)=\sum_{n=1}^{N} \sum_{m=0}^{n}\left(\delta C_{n m}(t) \cos (m \lambda)+\delta S_{n m}(t) \sin (m \lambda)\right) P_{n m}(\cos \theta)$,

where $\delta C_{n m}(t)$ and $\delta S_{n m}(t)$ are the normalized Stokes coefficients provided by GRGS (Biancale et al. 2006), $n$ and $m$ are the degree and order respectively and $N$ is the maximum degree of the decomposition, $\theta$ is the co-latitude, $\lambda$ is the longitude and $P_{n m}$ are the associated Legendre functions. Assuming that changes in the thickness of the ground water table is responsible for the $\delta G(t)$ anomaly, $\delta G(t)$ can be converted into changes in equivalent water height $\operatorname{EWH}(t)$. The water mass anomaly coefficients $\delta C^{h}{ }_{n m}(t)$ and $\delta S^{h}{ }_{n m}(t)$ of the $\mathrm{EWH}(\mathrm{t})$ harmonic series are estimated assuming a surface density associated with surface water mass $\delta h(t)$ as follows:

$$
\left\{\begin{array}{l}
\delta C_{n m}(t) \\
\delta S_{n m}(t)
\end{array}\right\}=W_{n}^{O}\left\{\begin{array}{l}
\delta C_{n m}^{h}(t) \\
\delta S_{n m}^{h}(t)
\end{array}\right\},
$$

where $W_{n}^{O}$ is an isotropic spatial filter that weights the surface density coefficients and the analytical expression of which is (Ramillien et al., 2005):

$$
W_{n}^{O}=\frac{4 \pi G R_{E} \rho_{w}}{(2 n+1) \gamma(\theta)}\left(1+k_{n}\right),
$$

where $k_{n}$ is the elastic Love numbers for degree $n, \gamma(\theta)$ is taken as the WGS84 standard normal gravity acceleration in the GRS80 reference ellipsoid at the co-latitude $\theta, G \approx 6.67$ $\mathrm{x} 10^{-11} \mathrm{~m}^{3} \mathrm{~kg}^{-1} \mathrm{~s}^{-2}$ is the gravitational constant, $R_{E} \approx 6,378 \mathrm{~km}$ is the mean Earth's radius and $\rho_{w} \approx 1,000 \mathrm{kgm}^{-3}$ is the water density.

The EWH time series were computed at the location of all available HS making the EWH and HS series directly comparable. The reference date of each grid is taken as the $15^{\text {th }}$ day of the interval. The mean amplitude of the GRACE EWH during the 4-year period of analysis is shown in Figure 1.

\section{Data Validation}

There are few water table piezometer data in the Amazon basin, and almost none of them are publicly distributed. Thus, the EWH cannot be validated directly by comparison with underground in situ data. However, the mass loading changes caused by water seasonal cycle produces crustal deflections that can be used to indirectly validate the EWH. The amplitude of the crustal radial displacements can be calculated by (Davis et al., 2004):

$r(\lambda, \phi, t)=R_{E} \sum_{n, m}\left(\frac{h_{n}^{E}}{1+k_{n}^{E}}\right) P_{n m}(\sin \phi) \times\left[\delta C_{n m}(t) \cos m \lambda+\delta S_{n m}(t) \sin m \lambda\right](5)$

where $\phi$ is the latitude, $k_{n}^{E}$ and $h^{E}$ are the elastic gravity and vertical load Love numbers respectively. $\delta C_{n m}(t)$ and $\delta S_{n m}(t)$ are the same Stokes coefficients as those used in Eq.2. Consequently, validation of radial displacements can be considered as an indirect validation of the EWH. Yet, the crustal deflections can be monitored by positioning network (Davis et al., 2004; Beavis et al., 2005)

In this scope, the crustal deflections estimated from GRACE have been compared to the height variations of a Global Positioning System (GPS) station installed in the center of the basin, where the largest crustal deflexion are expected, namely that of Manaus (acronym MAUS). Daily positions of MAUS have been computed using the Gins software developed at Centre National d'Études Spatiales (CNES) (Frey S. et al., 2002). The vertical component of these positions presents a clear semi-annual cycle. This cycle is consistent both in terms of phase and amplitude with the radial displacements deduced from GRACE mass anomalies using Eq. 5. It is worth noting that both signals are in phase with the gauge data. It is possible to conclude that although the series analyzed are short, the Stokes coefficients from GRACE, and hence the EWH are valid in this region.

\section{Error Analysis}

Three different sources of EWH errors have been considered: (1) uncertainties on the Stokes coefficients; (2) spectrum truncation due to the degree and order upper limit 50 imposed on the Stokes coefficients; (3) possible "leakage" of geophysical signals such as oceanic signals from surrounding regions that can pollute the EWH estimations.

Uncertainties on the Stokes coefficients are provided by GRGS together with the coefficient table. These coefficient errors $\delta \Delta c_{n m}(t)$ and $\delta \Delta s_{n m}(t)$ were expressed in terms of EWH. The error associated to the region considered was derived using a mask of the Amazon rim, developed in spherical harmonics 
the coefficients $A_{n m}$ and $B_{n m}$ of which take either the values "1" inside the mask and "0" outside. The uncertainty of the geographical average $\delta \Delta v(t)$ in terms of water volume error for the period $t$ considered, was estimated using (Ramillien et al., 2006):

$$
\delta \Delta v(t)=4 \pi R^{2} \sqrt{\sum_{n} \sum_{m}\left(\left(\delta \Delta c_{n m}(t) \times A_{n m}\right)^{2}+\left(\delta \Delta s_{n m}(t) \times B_{n m}\right)^{2}\right)}(\mathbf{6})
$$

Volume errors are converted into height errors $\delta \Delta H(t)$ as follows:

$$
\delta \Delta H(t)=\frac{\delta \Delta v(t)}{A_{B}},
$$

where $A_{B} \approx 6,110,000 \mathrm{~km}^{2}$ (ANA, 2006) is the surface of the Amazon basin.

EWH uncertainty deriving from uncertainties in the Stokes coefficients was estimated. The average amplitude is $-130 \mathrm{~mm}$ of EWH or $-800 \mathrm{~km}^{3}$ of water volume. This is consistent with results from previous studies (see for instance Wahr et al., 2006) that arrived at the same level of error, (i.e., $-150 \mathrm{~mm}$ based in regional estimates).

The effects of truncation were evaluated as the difference between two EWH signals, one developed up to degrees $N=50$ (i.e., $-450 \mathrm{~km}$, actual resolution of the GRGS solutions) and one developed to degree $N=200$ (i.e., considered as the full resolution of the starting global grid), at the same period and region. This test showed that the signals are nearly fully reconstructed at degree $N=50$ since the difference in EWH due to the coefficients truncation is limited to $10 \sim 15 \mathrm{~mm}$ for an averaging radius of 450-500 km, or equivalently, limited to less than $1 \mathrm{~km}^{3}$ in terms of water volume.

To evaluate the leakage error, an inverse mask disk of 450 $\mathrm{km}$ radius created at the station location was used, with values of " 0 " inside the disk and " 1 " outside. The spherical harmonic $A_{n m}^{\prime}$ and $B_{n m}^{\prime}$ corresponding to this mask were computed up to degree 200 . The averaged leakage effect $\Delta^{\prime} v(t)$ was calculated using the formula:

$$
\Delta^{\prime} v(t)=4 \pi R^{2} \sqrt{\sum_{n} \sum_{m}\left(\Delta^{\prime} c_{n m}(t) \times A_{n m}^{\prime}+\Delta^{\prime} s_{n m}(t) \times B^{\prime}{ }_{n m}\right)},
$$

where $\Delta c^{\prime}{ }_{m p}(t)$ and $\Delta s^{\prime}(t)$ were the continental water storage WGHM (WaterGAP Global Hydrology Model) outputs (Döll et al., 2003) converted into spherical harmonics for the considered period $t$. In case of no leakage, $\Delta^{\prime} v(t)$ should be close to zero.

Attention was given to the leakage effects from continental water WGHM only, although other water mass reservoirs are known to create leakage errors, too (e.g., oceanic mass errors from the removal of oceanic and atmospheric models to GRGS/CNES geopotential fields).
The effect of leakage of continental waters (surface water, groundwater and snow) using the WGHM model outputs was computed. Seasonal amplitude from leakage of continental waters can reach $-21 \mathrm{~mm}$ of equivalent-water height (or $\sim 130$ $\mathrm{km}^{3}$ of water volume). This error decreases with the distance from the estuary, suggesting less leakage effects in the center of the basin, from $-12.0 \mathrm{~mm}$ in Tabatinga $(3143 \mathrm{~km}$ away from the estuary) to $-33.2 \mathrm{~mm}$ in Santarém (799 km away from the estuary).

The total error budget reaches $10 \%$ of the signal amplitude. These errors have been accounted for in the following sections to evaluate the uncertainty of the regression coefficients, using classical laws of error propagation.

\section{RESULTS AND DICUSSION \\ EWH versus HS regressions - The correlation coefficient $\boldsymbol{R}^{2}$}

The Pearson coefficient is defined as:

$$
R=\frac{\operatorname{Cov}(E W H(t), H S(t))}{\sigma_{E W H(t)} \cdot \sigma_{H S(t)}},
$$

where $E W H(t)(\mathrm{mm})$ and $H S(t)(\mathrm{mm})$ correspond to the respective values of GRACE and in situ water level time-series respectively at epoch $t$; and $\sigma_{E W H(t)}$ and $\sigma_{H S(t)}$ correspond to the standard deviation of $E W H(t)$ and $H S(t)$ respectively.

The geographical distribution of the correlation coefficient (squared Pearson coefficient) $R^{2}$ in the Amazon basin has been analyzed between in situ water level and GRACE series for the same site. Globally $R^{2}$ decreases from the center of the basin toward the borders as shown in Figure 2. Spot of very high correlation (black areas in Figure 2) are found:

1. Southwest part of the basin;

2. on the middle Purus River;

3. in the center of the basin, where Solimóes, Negro and Madeira Rivers are converging;

4. just upstream of The Tapajós River.

Location of rivers is reported in Figure 3. These spots of high correlation are places where large amounts of water are accumulating at high stage. Lowest correlation occurs in Balbina (lat: $1.9^{\circ} \mathrm{S}$, long: $59.5^{\circ} \mathrm{W}$ ), where the level of a reservoir is man-controlled. Low correlation is found at the origin of most Amazon tributaries, namely the Tapajós and Branco Rivers. Some tributaries homogeneously flow within a high correlation area (ex: Madeira River) and others run through domains of variable correlation (Tapajós, Negro, Xingu Rivers). At the rim of the basin, the low correlation area may correspond to domains where the GRACE resolution $(\sim 450 \mathrm{~km})$ includes mass variations of neighboring basins such as the Orinoco basin in the NW or the Tocantins basin 
in the SE. In the SW part, the correlations remain high. Yet, the Pantanal wetland makes a continuity of the water table between the Amazon and the Paraná basins. The low correlation area located from Xingu to the estuary may be due to contamination of the HS series by oceanic signals.

In terms of geological domains (Figure 3), it must be stressed that high correlations underline the sedimentary basins of the Solimóes-Amazon and Andean piedmont, whereas low correlations are characteristic of the Guiana and Guaporé shields.

\section{Square linear adjustment}

A linear adjustment of the EWH and HS pairs of time series was carried out for the 233 stations and a local linear transfer function was computed, that is, the best fitting

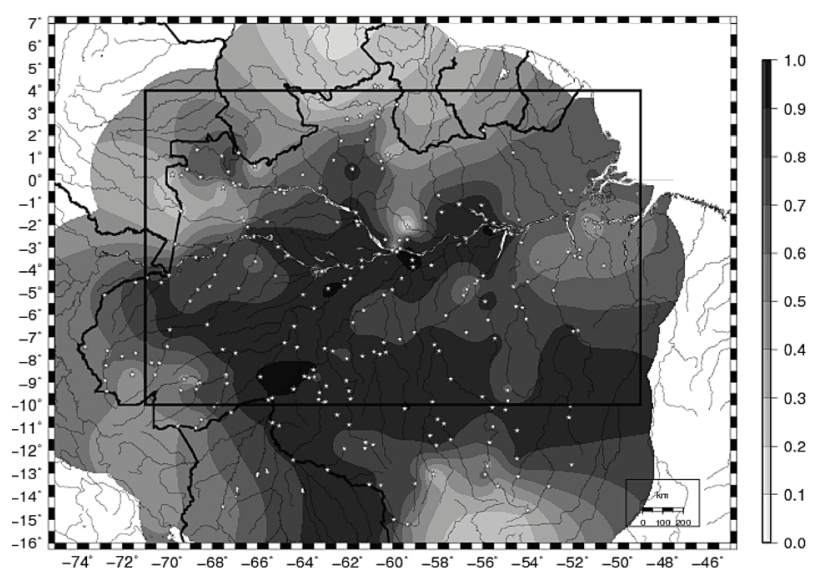

Figure 2 - Correlation coefficient $\left(R^{2}\right)$ distribution for the Amazon Basin area.

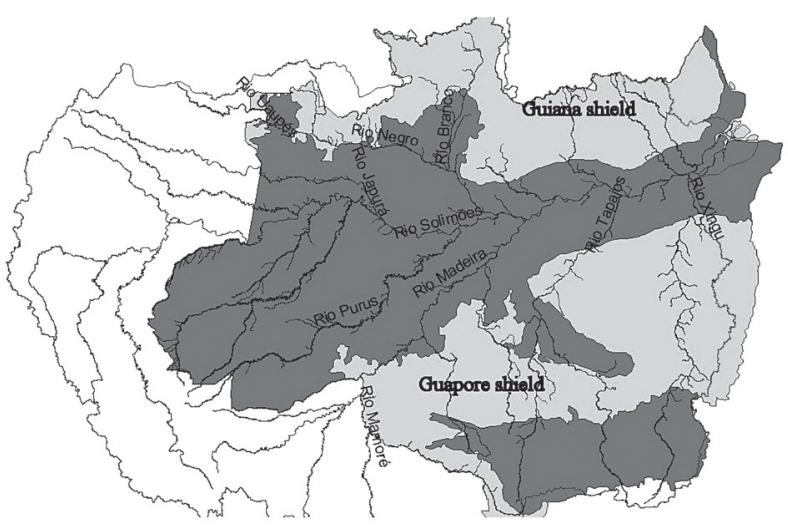

Figure 3 - Geographical distribution of the sedimentary basins (dark gray) and shields (light gray) in the Brazilian part of the Amazon basin. Names of the major contributors are provided. regression line between in situ and GRACE data, assuming a linear relationship:

$$
H S(t)=a \cdot E W H(t)+b,
$$

where $a$ (dimensionless) is the slope of the best fitted regression line and $b$ is the mean of the $\mathrm{HS}(\mathrm{t})$ series given that the $\mathrm{EWH}(\mathrm{t})$ series have almost zero means.

\section{The slope coefficient $\boldsymbol{a}$ of the regression lines}

In this part of the paper the results obtained for stations where the correlation coefficient is greater than 0.7 (Table 1) is discussed, i.e. at the station where potentially in situ water level and GRACE signals are related linearly.

Table 1 - The correlation coefficient $R^{2}$ (dimensionless) and regression coefficient a (dimensionless) for some stations and its distance from river mouth $(\mathrm{km})$.

\begin{tabular}{|c|c|c|c|c|}
\hline & Station name & $\mathrm{R}^{2}$ & a & Distance \\
\hline \multirow{7}{*}{ Solimões } & Tabatinga & 0,77 & 19,63 & 3143 \\
\hline & S.P. Olivença & 0,79 & 16,65 & 2912 \\
\hline & S.A. do Iça & 0,79 & 15,79 & 2771 \\
\hline & Fonte-Boa & 0,81 & 13,08 & 2457 \\
\hline & Tefe-Missões & 0,87 & 11,12 & 2200 \\
\hline & Itapeuá & 0,85 & 9,08 & 1983 \\
\hline & Manacapuru & 0,87 & 9,37 & 1660 \\
\hline \multirow{5}{*}{ Amazonas } & Jatuarana & 0,90 & 9,33 & 1538 \\
\hline & Parintins & 0,89 & 8,03 & 1110 \\
\hline & Óbidos & 0,88 & 7,27 & 921 \\
\hline & Santarém & 0,90 & 6,57 & 799 \\
\hline & Macapá & 0,55 & 1,13 & 233 \\
\hline \multirow{6}{*}{ Negro } & Cucui & 0,77 & 20,27 & 2780 \\
\hline & São Felipe & 0,74 & 19,03 & 2623 \\
\hline & São Gabriel da Cachoeira & 0,63 & 11,84 & 2552 \\
\hline & Barcelos & 0,79 & 7,68 & 2026 \\
\hline & Moura & 0,89 & 10,35 & 1866 \\
\hline & Manaus & 0,87 & 9,45 & 1580 \\
\hline \multirow{5}{*}{ Madeira } & Porto Velho & 0,89 & 17,74 & 2478 \\
\hline & Humaitá & 0,85 & 15,87 & 2237 \\
\hline & Manicore & 0,73 & 12,51 & 1882 \\
\hline & Borba & 0,85 & 10,04 & 1588 \\
\hline & Nova Olinda do Norte & 0,91 & 8,91 & 1501 \\
\hline \multirow{2}{*}{ Branco } & Boa Vista & 0,48 & 6,81 & 2421 \\
\hline & Caracarai & 0,65 & 9,55 & 2284 \\
\hline \multirow{2}{*}{ Tapajós } & Jatobá & 0,60 & 5,04 & 1240 \\
\hline & Itaituba & 0,84 & 7,90 & 1071 \\
\hline Aripuanã & Prainha Velha & 0,80 & 13,73 & 2027 \\
\hline Roosevelt & Fazenda Boa Lembrança & 0,86 & 9,94 & 2090 \\
\hline \multirow{2}{*}{ Uaupés } & Uaracu & 0,66 & 14,87 & 2888 \\
\hline & Taraqua & 0,65 & 14,05 & 2764 \\
\hline \multirow[t]{2}{*}{ Xingu } & Boa Sorte & 0,87 & 10,14 & 1336 \\
\hline & Average & $\sim 0,8$ & - & - \\
\hline
\end{tabular}


The regression coefficient $a$ generally decreases from up to down stream in all the major rivers in this study (Table 1). Along the Solimóes-Amazon system, $a$ regularly decreases from -20 to -1 . Yet, 1 is the theoretical floor value for $a$ since it stands for height variations of a volume made of $100 \%$ of water, as it is the case over the ocean. The decreasing trend of $a$ along the river courses can be interpreted in two ways: (1) either the annual water level amplitude decreases more rapidly along the river than the total water storage does, or (2) the range of HS variations varies little from up to down stream with respect to annual changes of the total water storage. This would mean that the ground/underground water storage decreases towards the Amazon River estuary in the first case and increases in the second. It should be noted that the place where the EWH signal has the largest amplitude, i.e. roughly at the Negro-Solimóes-Madeira confluence, is not the place where extreme values of $a$ are found. It is just marked as the place where $\delta^{2} a / \delta x^{2}$ ( $x$ is the station distance to mouth) changes in sign, being positive along the Solimóes and turning negative along the Amazon. Then, low $a$ values are not simply due to large amplitude EWH signals. This decrease of the $a$ coefficient along the course of the river was interpreted as an increased control of the river flow by the underground waters.

Yet, the decrease of $a$ is not identical for all rivers. For rivers such as the Madeira, a very linear decrease is observed versus the distance along the river. For rivers such as the Solimôes and Amazon, the regression coefficient decrease quadratically, with opposite curvatures. Last, the Negro, Tapajós and Xingu Rivers present non-linear decrease of the along-course regression coefficient.

As aforementioned for the $R^{2}$ coefficient, the way $a$ evolves along the river course is geographically related to the geological domains that the river crosses. The Madeira River runs entirely in the central sedimentary band of the basin (Figure 3). The rivers presenting marked second order variations of $a$ crosscut distinct hydrological domains, either shields or sedimentary basins.

\section{Phase study}

Firstly, for a phase analysis, the correlation coefficient $R^{2}$ was recalculated for $30 \mathrm{HS}$ in relation to EWH, in main basin tributaries, for different phase-shifts $( \pm 1, \pm 7$ and \pm 15$)$ days, arbitrary data sampling unlike GRACE cycles (10-day). Thus, the best result of the $R^{2}$ values for $70 \%$ of the sampled stations were obtained for null phase-shift, (i.e. \pm 0 day phase-shifted) between in situ water level and GRACE series. For an in-depth analysis, these series were separated as follows.

The water level series for all stations were separated in so-called high waters and low waters types. The criteria for this separation were taken respectively as above or below the historical water average. Thus, the coefficients of correlation
$R^{2}$ and the slope coefficient $a$ were calculated for these partial series. The average of $R^{2}$ over all stations was decreased from $R_{\text {avg }}^{2}=0.709$ to $R_{\text {bigh water }}^{2}=0.426(-39.93 \%)$ for high waters and to $R_{\text {low water }}^{2}=0.376(-46.94 \%)$ for low waters. Consequently, these changes in the coefficients demonstrates a bad sensitivity of the GRACE mission for the conditions of drought and flood periods, in which stronger local rains can represents significant variations in the height of water in short periods of time.

A second approach was taken over the historical water level series, as splitting the series in rising and falling waters between the minimum and maximum level reached at each annual cycle. The averaged coefficient $R_{a v g}^{2}$ was changed to $R_{\text {incr }}^{2}=0.775(+9.27 \%)$ and $R_{\text {decr }}^{2}=0.730(+2.98 \%)$ for the rising and decreasing waters, respectively. Thus, is possible to interpret that GRACE presents a better sensitivity to strong water level variations than to slowly varying heights during the drought and flood periods.

The increasing and decreasing waters analysis was extended to a study of the out-of-phase semi-annual cycle. The pairs of series at each station were visually classified into 6 found types:

1. Noisy - All stations where strong high-frequency signals present the HS signal corrupt the correspondence between both series (Figure 4a);

2. All-in-phase: both series are in phase (Figure 4b);

3. HS rises before and falls in phase: The HS rises before than EWH but both fall together (Figure 4c);

4. Rise in phase and EWH falls before: Both series rises in phase, but EWH decreases before (Figure 4d);

5. Rise in phase and HS falls before: Both series rises in phase, but HS decreases before (Figure 4e);

6. HS rises and falls before: The surface water level series HS increase and decrease in advance of EWH series (Figure 4f);

7. EWH rises and falls before: The historical EWH increase and decrease in advance of HS series (Figure 4g);

8. Indefinite - The undefined stations (Figure 4h).

The results of this classification are presented in the Table 2 .

The geological units shown in Figure 3 also constitute distinct hydrological units. These hydrological units seem to control the type of relationship between $\mathrm{HS}$ and $\mathrm{EWH}$ since the various types of series are predominantly found in distinct hydrological domains (Figure 5).

Types 2 and 3 are mostly found in the central sedimentary-basin. Type 2 (no phase shift) is almost limited to the main stream when type 3 series mostly occur on 
a)

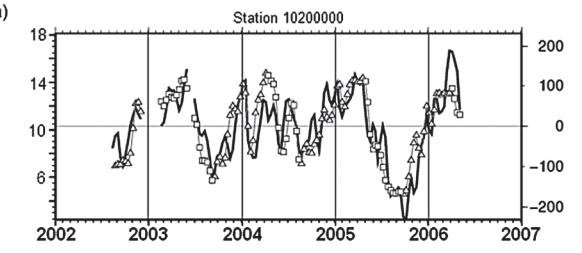

b)

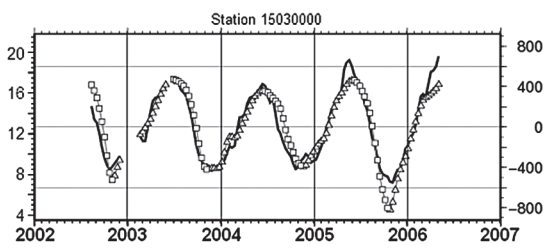

c)

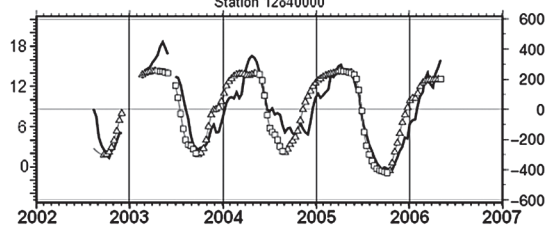

d)

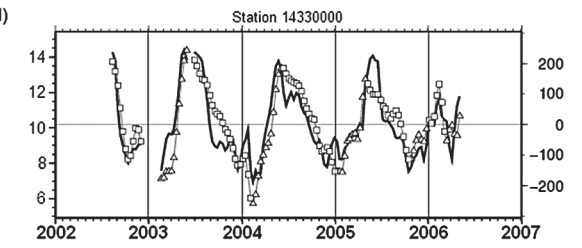

e)

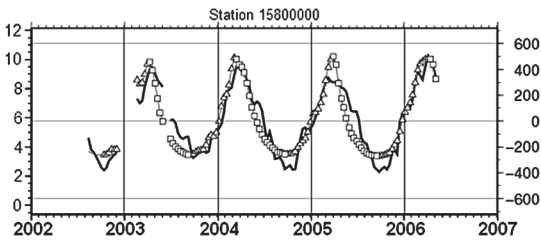

f)

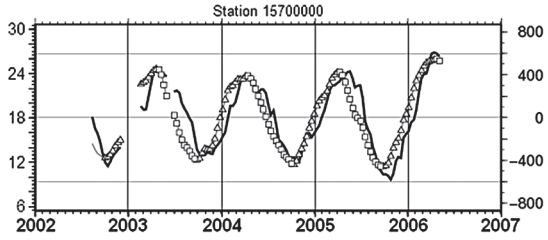

g)

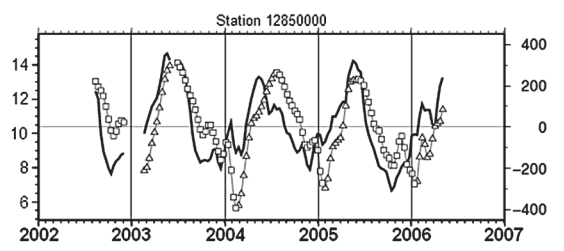

h)

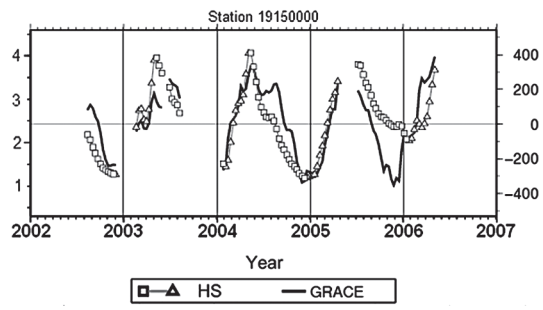

Figure 4 - Sample out-of-phase type Classification. Hydrological Station (m) left and GRACE $(\mathrm{mm})$ right.
Table 2 - Number of stations by phase type characterization.

\begin{tabular}{cc}
\hline Classification & Number of Stations \\
\hline All-in-phase & 68 \\
\hline Both-GRACE & 8 \\
\hline ANA-Both & 9 \\
\hline Both-ANA & 44 \\
\hline ANA-ANA & 47 \\
\hline GRACE-GRACE & 4 \\
\hline Noisy & 17 \\
\hline Indefinite & 3 \\
\hline Not classified & 33 \\
\hline Total & 233 \\
\hline
\end{tabular}

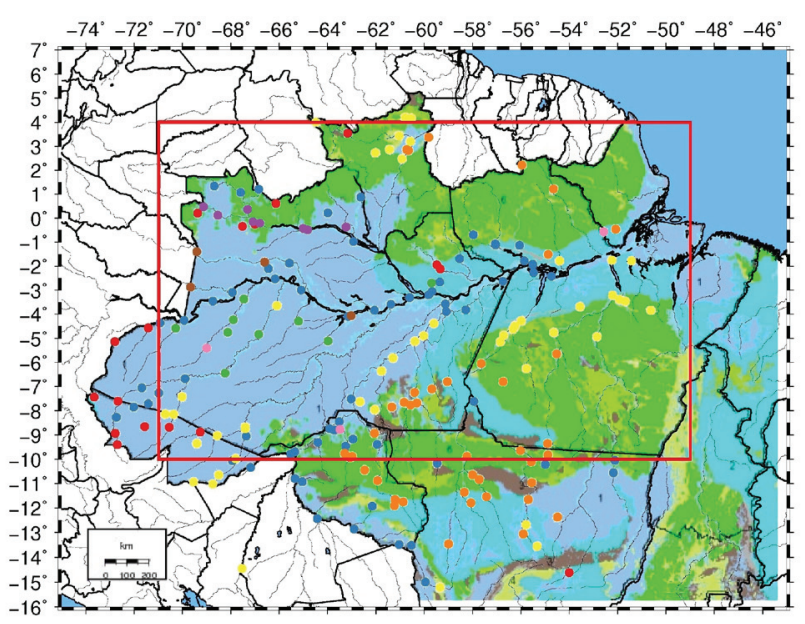

Figure 5 - Hydrological Map with HS types (1-Noisy, 2-All-in-phase, 3-HS rises before and falls in phase, 4-Rise in phase and EWH falls before, $\mathbf{5}$-Rise in phase and HS falls before, 6-HS rises and falls before, 7-EWH rises and falls before, 8-Indefinite). Sedimentary basins are represented in light gray and crystalline basins are represented in dark gray.

tributaries. This means that in this sedimentary basin, the underground water and river have strong connections ensuring a rapid equilibrium between both reservoirs during the rise phase. During the phase of decreasing stages, the water table level decreases after that in the river beds when both decrease together in the Solimóes-Amazon main stream.

Type 5 series pairs characterized by clear phase shift are typical of the shield domains or the boundary between shield and sedimentary basins. In these cases, the water table fills before the river. This can be explained by the high fracturation of the shield domains, making a small amount of the input rain percolate rapidly in a low porosity ground. As aforementioned, these shield areas also correspond to high correlation coefficient. This is also consistent with the hypothesis of non-equilibrium between both water bodies. 
Type 6 series denotes cases in which the EWH decreases earlier than the HS. These cases are mostly located at the boundary between hydro-geological domains. These cases can be interpreted as produced by the lack of spatial resolution of the GRACE maps. Indeed, no hydrological conditions can explain that EWH decreases faster than HS. Thus, it can be inferred that the EWH signal is a merge of different time variation regimes occurring in the contiguous hydrogeological domains.

Type 1 series, evidencing the absence of clear relation between EWH and HS, are located in the Andean piedmont, in the westernmost part of the basin. This can be explained as a strong decoupling of the flow in the river and the water table. There, where the relief slope is large, rainfalls rapidly flow into river beds and few percolate in the ground to feed the water table, making poor correlation between the rivers IS and the water table EWH.

\section{CONCLUSION}

The high correlation relating GRACE equivalent water heights and measured river levels at more than 230 locations in the Amazon basin was evident. Proportionality coefficient between both signals varies between -20 in the upstream part of the rivers to 1 at the Amazon estuary. Six types of series pairs have been identified in the dataset, as both signals rise and fall in phase or present out-of-phase rise and/or fall regimes. Altogether the correlation coefficient, the proportionality coefficient and the series classification reveal the control of the hydrogeological domains in the interaction between ground water and river in time. In the central sedimentary basins, the underground and river waters time-variations are highly correlated, their proportionality decreases regularly from up to down stream and both signals are rather in phase. On the shields, where not much underground water is stored, the underground and river water variations are less correlated, the proportionality coefficient varies significantly locally and the series pairs present out of phase regimes. It should be noted that since the shields are mostly located on the rim of the basin, contribution of adjacent hydrographic basins to the GRACE signal may be partly responsible for the lesser correlation found around.

Yet, hydrological basin, which is delimited by the topography, appears as an inhomogeneous entity in terms of relationship between the river flow and the underground water storage. Homogeneity is found at the level of the hydrogeology units. Consequently, it is suggested that the geographical extension of these domains might be a better candidate than the watershed contours to delimitate the mass units in defining regions for averaging GRACE signals.

\section{BIBLIOGRAPHY}

ANA - Agência Nacional de Águas, 2006. Amazon River Basin: Informations about the basin. (http://www.ana.gov.br). Accessed: 22 feb 2007 (in Portuguese).

Bevis, M., Alsdorf, D., Kendrick, E., Fortes, L. P., Forsberg, B., Smalley, R., Becker, J., 2005. Seasonal fluctuations in the mass of the Amazon River system and Earth's elastic response; Geophysical Research Letters, 32: L16308.

Biancale, R., Lemoine, J.-M., Balmino, G., Loyer, S., Bruisma, S., Pérosanz, F., Marty, J.-C., Gégout, P., 2006. 3 years of geoid variations from GRACE and LAGEOS data at 10-day intervals from July 2002 to March 2005, CNES/GRGS products, data available on CD-ROM.

Bruinsma, S., Lemoine, J.-M., Biancale, R., Valès, N., 2010. CNES/GRGS 10-day gravity field models (release 2) and their evaluation, Advances in Space Research, 45: 587-601.

Davis, J. L., Elósegui, P., Mitrovica, J. X., Tamisiea, M. E., 2004. Climate-driven deformation of the solid Earth from GRACE and GPS, Geophysical Research Letters, 31: L24605.

Döll, P., Kaspar, F., Lehner, B., 2003. A global hydrological model for deriving water availability indicators: model tuning and validation, Journal of Hydrology. 270: 105-134.

ECMWF, 1991. ECMWF research manual. European Center for Medium-Range Forecasts Model.

Frey, S., et al. 2002. Geodetic Space VLBI: The first test observations, Advances in Space Research, N. 2, 30: 357-361.

Lemoine, J.-M., Bruisma, S., Loyer, S., Biancale, R., Marty, J.-C., Pérosanz, F., Balmino, G., 2007. Temporal gravity field models inferred from GRACE data, Advances in Space Res., in press.

Lyard, F., Lefèvre, F., Letellier, T., Francis, O., 2006. Modelling the global ocean tides: a modern insight from FES2004, Ocean Dynamics, 56: 394-415.

Ramillien, G., Frappart, F., Cazenave, A., Güntner A., 2005. Time variations of the land water storage from an inversion of 2 years of GRACE geoids, Earth Planetary Science Letters., 235: 283-301.

Ramillien, G., Lombard, A., Cazenave, A., Ivins, E.R., Llubes, M., Remy, F., Biancale, R., 2006. Interannual variations of the mass balance of the Antarctica and Greenland ice sheets from GRACE, Global and Planetary Change, 53: 198-208.

Ramillien, G.,. Famiglietti, J. S., Wahr, J., 2008. Detection of Continental Hydrology and Glaciology Signals from GRACE: A Review, Surveys in Geophysics, 29: 361-374.

Schmidt, R., Flechtner, F., Reigber, Ch., Schwintzer, P., Güntner, A., Döll, P., Ramillien, G., Cazenave, A., Petrovic, S., Jochman, H., Wunsch, J., 2006. GRACE observations of changes in continental water storage, Global and Planetary Change, 50/12: $112-126$. 


\section{ACTA}

Schmidt, R., Flechtner, F., Meyer, U., Neumayer, K.H., Dahle, Ch., König, R., Kusche, J., 2008. Hydrological Signals Observed by the GRACE Satellites, Surveys in Geophysics, 29: 319-334.

Tapley, B.D., Bettadpur, S., Watkins, M., Reigber C., 2004a. The Gravity Recovery and Climate Experiment: Mission overview and Early results, Geophysical Research Letters, 31: L09607.

Tapley, B.D., Bettadpur, S., Ries, J.C., Thompson, P.F., Watkins M., 2004b. GRACE measurements of mass variability in the Earth system, Science, 305: 503-505.
Wahr, J., Swenson, S., Zlotnicki, V., Velicogna, I., 2004. Timevariable gravity from GRACE: first results, Geophysical Research Letters, 31: L11501.

Wahr, J., Swenson, S., Velicogna, I., 2006. Accuracy of GRACE mass estimates, Geophysical Research Letters, 33: L06401.

Recebido em 29/09/2010

Aceito em 16/12/2010 
